\title{
Variations in the squamous part of the occipital bone in medieval and contemporary cranial series from Bulgaria
}

\author{
S. Nikolova ${ }^{1}$, D. Toneva ${ }^{1}$, Y. Yordanov ${ }^{1}$, N. Lazarov², 3 \\ ${ }^{1}$ Institute of Experimental Morphology, Pathology and Anthropology with Museum, Bulgarian Academy of Sciences, \\ Sofia, Bulgaria \\ ${ }^{2}$ Department of Anatomy and Histology, Medical University of Sofia, Sofia, Bulgaria \\ 3/nstitute of Neurobiology, Bulgarian Academy of Sciences, Sofia, Bulgaria
}

[Received 20 March 2014; Accepted 26 April 2014]

\begin{abstract}
The squamous part of the occipital bone is a place of many different variations. They are a result of faulty ossification in the occipital squama or due to the presence of sutural bones in the lambda region. As their differentiation is intricate because of the various criteria used, the issue of their recognition in the adult skull still remains difficult even though they can be clearly distinguished at a younger age. The aim of the present study was to compare the frequency of interparietal, preinterparietal and sutural bones in the lambda region in medieval male and female cranial series as well as between medieval and contemporary male series from Bulgaria. We also discuss the development of the occipital squama in order to set clearer criteria for further differentiation of such variations in the adult skull. In the reviewed 3 cranial series, the variations in the squamous portion of the occipital bone were observed with a low frequency. The incidence of preinterparietal bones was more common than the interparietal ones. The sutural bones in the lambda region were numerous in the series. No statistically significant sex or intergroup differences were established. So even if these anatomical variations are relatively rare, the understanding of them is of significance for many disciplines like anthropology, comparative and developmental anatomy, clinical and forensic medicine. (Folia Morphol 2014; 73, 4: 429-438)
\end{abstract}

Key words: interparietal bone, preinterparietal bone, sutural bones

\section{INTRODUCTION}

The squamous part of the occipital bone is an intricate site where different variations are observed and reported. Indeed, the presence of such variations is due to faulty ossification in the occipital squama, which consists of two parts - a supraoccipital and interparietal one $[16,17,22,23,27,30,31]$.

The supraoccipital part is situated between the highest nuchal line and the posterior margin of the foramen magnum. It articulates anteriorly with the la- teral occipitals at the sutura intraoccipitalis posterior. The supraoccipital part consists of 2 segments: torus occipitalis transversus or the so-called lamina triangularis, a membranous part between the highest and superior nuchal lines, and a lower cartilaginous part.

The interparietal part is a triangular space situated between the highest nuchal line and both parietal bones. It undergoes membranous ossification and forms the posterior wall of the cranial cavity. During the foetal life the supraoccipital and interparietal

Address for correspondence: S. Nikolova, PhD, National Anthropological Museum with Research Group, Institute of Experimental Morphology, Pathology and Anthropology with Museum, Bulgarian Academy of Sciences, Acad. G. Bonchev Str., BI. 25, BG-1113 Sofia, Bulgaria, tel: +359-2-9792318, fax: +359-2-8710107, e-mail: sil_nikolova@abv.bg 
parts fuse with each other to form the squamous portion of the occipital bone $[16,17,22,23,27,29-31]$.

From a phylogenetic aspect, the interparietal or postparietal bone is an ancient integrated portion of the reptilian and mammalian skull [29]. In different species the interparietal bone can be fused with the parietals; it can persist as a separate bone or can be fused with the supraoccipital segment of the occipital bone, as it is usually in humans $[29,31]$.

The true interparietal part of the occipital bone, above the highest nuchal line, forms from a variable number of ossification centres, which arise in the membrane above the supraoccipital. There are many questions concerning the origin and pattern of fusion of these centres, which cause the numerous variations in this part of the skull. Furthermore, the lambda is a common place for the development of sutural or Wormian bones from their own ossification centres $[20,24]$. This in turn leads to additional confusion in the classification of variations. However, as most of the descriptions are derived from adult specimens, their true embryological origin can only be supposed. Moreover, when investigating adult skulls, it is often barely possible to assess if the bones are a result of a faulty fusion of any of the interparietal centre(s) with the rest of the interparietal part of the occipital bone [31]; if they appear as a consequence of an occasional specific pair of centres called preinterparietal [16], or if they are sutural bones that developed from their own ossification centres with no relation with the occipital squama and its ossification.

Many researchers report single cases and/or varying frequency of interparietal, preinterparietal and sutural bones in the lambda among the different ethnical groups and populations $[2,3,5-7,9-15,18$, $21,25,26,28,32,33,35,36]$. One extensive study devoted to the frequency of os Incae was performed by Hanihara and Ishida [8]. However, it is difficult or sometimes impossible to compare these data, because most of the authors use various criteria for differentiation of the os Incae or interparietal bone from the preinterparietal and sutural bones in the lambda region. On the other hand, such a differentiation is important because of the increasing implication of these variations as non-metric epigenetic cranial traits in population studies [22].

Doubtless, when the objects of investigation are adult skulls, it is necessary to distinguish all the possible variations from the conventional os Incae. Therefore, it is significant for anthropologists, anatomists and other researchers dealing with bone material to use precise definitions and unified terminology for each variation observed in the occipital squama and the lambda region. Once this is established clearly, it will be much easier to describe and compare the variations in this region, especially in individuals of advanced age.

The aim of the present study was to compare the frequency of interparietal, preinterparietal and sutural bones in the lambda region in the medieval male and female cranial series as well as between the medieval and contemporary male series from Bulgaria. We further attempt to discuss and distinguish the possible variations, based on the development of the squamous part of the occipital bone described by different researchers $[16,17,22,23,30,31]$. We have also tried to compare their observations and results in order to obtain more certain and clear criteria for further discrimination of the variations in this region of adult skulls.

\section{MATERIALS AND METHODS}

Variations in the squamous part of the occipital bone, i.e. the presence of interparietal, preinterparietal and sutural bones, were investigated in 515 skulls belonging to adult individuals from both sexes. The skulls were grouped into 3 cranial series: contemporary male series (CMS), medieval male series (MMS) and medieval female series (MFS). The CMS consisted of 199 well preserved skulls from the ossuary of the Bulgarian National Museum of Military History. The MMS (158 skulls) and MFS (158 skulls) were samples from different necropoles, and also part of the bone collection of the Institute of Experimental Morphology, Pathology and Anthropology with Museum, Bulgarian Academy of Sciences. The age and sex of the individuals were previously determined.

The presence of interparietal, preinterparietal and sutural bones was determined through a macroscopic observation of the squamous part of the occipital bone and the lambda region. The differentiation of interparietal, preinterparietal and sutural bones was done using summarised criteria described by different authors $[16,22,31]$. The different types of the interparietal bone or the so-called os Incae were named using the scheme and classification of Kadanoff and Mutafov (Fig. 1) $[9,10]$.

Verification of the statistical significance of the established sexual and intergroup differences was performed by the $\chi^{2}$ test. 


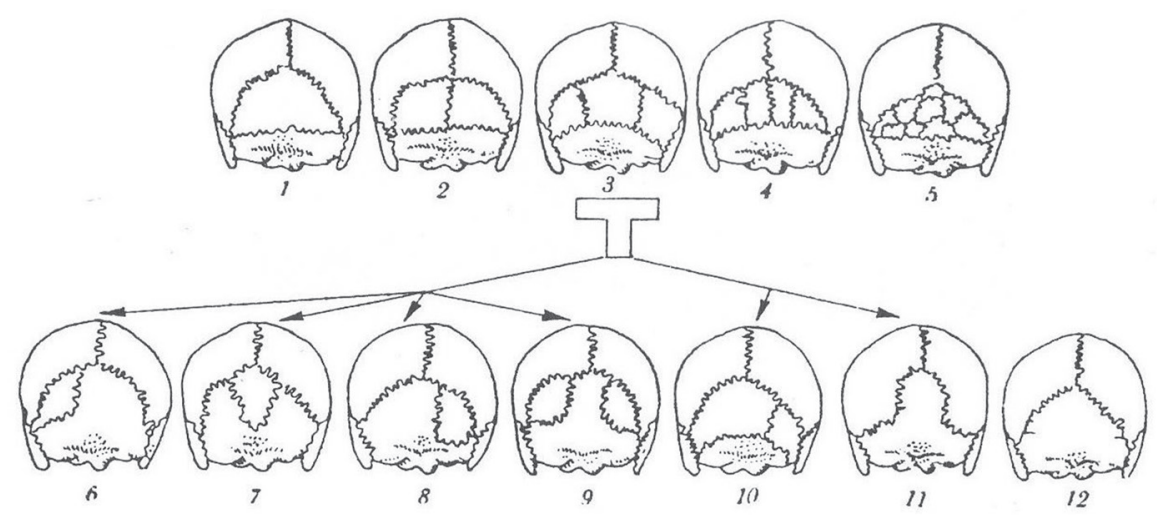

Figure 1. Classification of different types of Os Incae after Kadanoff and Mutafov (1968; 1984). 1 - Os Incae totum; 2 - Os Incae bipartitum; 3 - Os Incae tripartitum; 4 - Os Incae quadripartitum; 5- Os Incae multipartitum; 6-Os Incae laterale sinistrum; 7 - Os Incae centrale (medianum); 8 - Os Incae laterale dextrum; 9 - Os Incae duplex symmetricum; 10 - Os Incae duplex asymmetricum; 11 - Pars incoidea squamae occipitalis (processus sagittalis squamae occipitalis); 12 — remnant of sutura mendosa.
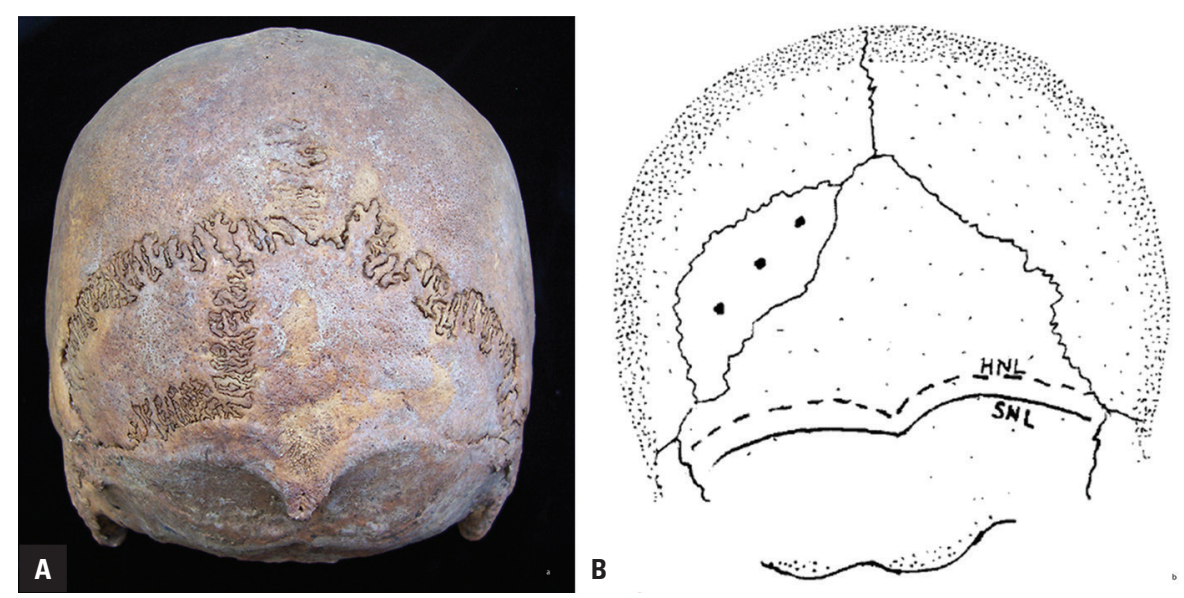

Figure 2. Os Incae laterale sinistrum. A. In the contemporary male series; B. A scheme of the possible mechanism of its formation by union of upper and lower nuclei of the third pair with the lateral nucleus of the second pair, and failure of their fusion with the rest of the interparietal on the left side, according to Yücel et al. (2001) using Srivastava's description (1992); HNL — highest nuchal line; SNL — superior nuchal line.

\section{RESULTS}

Mainly single cases of the different types of interparietal bone or os Incae were observed in the investigated three cranial series. In the CMS, we established $2(1.0 \%)$ cases of os Incae laterale sinistrum (Fig. 2A, B), $1(0.5 \%)$ case of os Incae laterale dextrum (Fig. 3) and 1 (0.5\%) case of os Incae asymmetricum (Fig. 4). Among the MMS we recorded a single (0.6\%) case of os Incae tripartitum (Fig. 5A, B), 1 (0.6\%) case of os Incae laterale sinistrum and $1(0.6 \%)$ case of os Incae laterale dextrum. In the MFS, we found only a single $(0.63 \%)$ case of os Incae tripartitum in a combination with sutural bones above it (Fig. 5C). Isolated (0.6\%) cases of os Incae laterale sinistrum

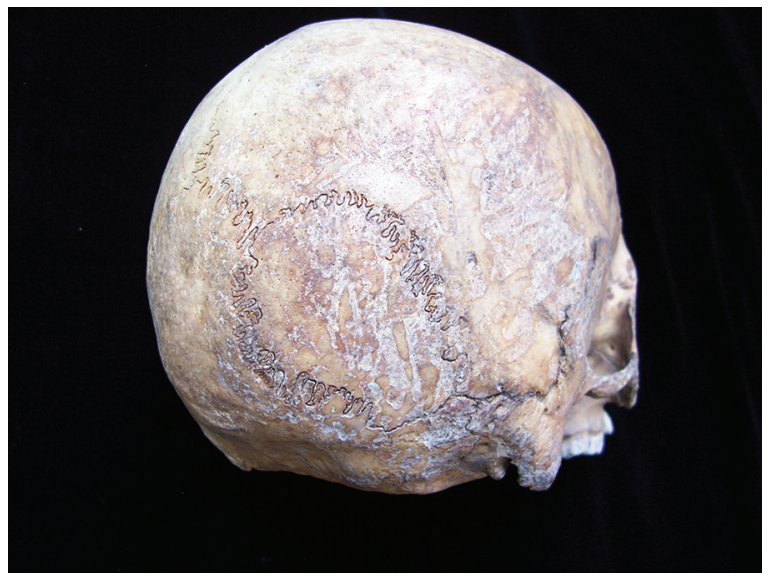

Figure 3. Os Incae laterale dextrum in the contemporary male series. 


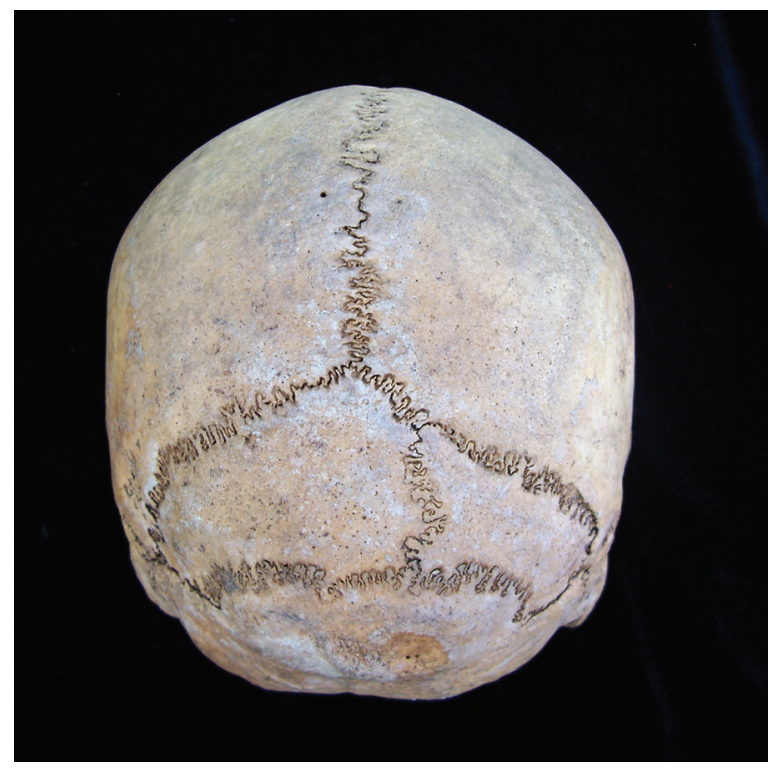

Figure 4. Os Incae asymmetricum in the contemporary male series.

and os Incae centrale (medianum) (Fig. 6A, B) were also observed. There was $1(0.6 \%)$ incidence of os Incae, representing a separate bone formed by three-fourths of the interparietal bone (Fig. 7). This type of interparietal bone was not presented in the scheme of Kadanof and Mutafov $[9,10]$. According to the classification of Hanihara and Ishida [8], this variation corresponds to os Incae Type II.1 (Fig. 8).

The incidences of preinterparietal bone were numerous compared to those of os Incae. In the CMS, $4(2.0 \%)$ cases of single preinterparietal bone (Fig. 9A), $1(0.5 \%)$ case of bipartite preinterparietal (Fig. 10A) and $2(1.0 \%)$ cases of multipartite preinterparietal were established as in one of the latter the multipartite preinterparietal bone was in a combination with os Incae laterale sinistrum (Fig. 11A, B). Amongst the MMS a single preinterparietal bone was found in $7(4.4 \%)$ cases (Fig. 9B), while the bipartite (Fig. 10B) and multipartite ones were established in isolated $(0.6 \%)$ cases. The incidences of single preinterparietal bone in MFS were numerous again $-5(3.2 \%)$ cases, in comparison with the observed $2(1.3 \%)$ cases of bipartite preinterparietal bone and another $2(1.3 \%)$ cases of multipartite one.

The frequency of sutural bones in the lambda region was also recorded. They were numerous in the CMS $-13(6.5 \%)$ cases, followed by those of MFS - 10 (6.3\%) cases and MMS - 9 (5.7\%) cases (Fig. 12A-D). Despite its large size, the accessory bone at the lambda in Figure 12B was considered a sutural
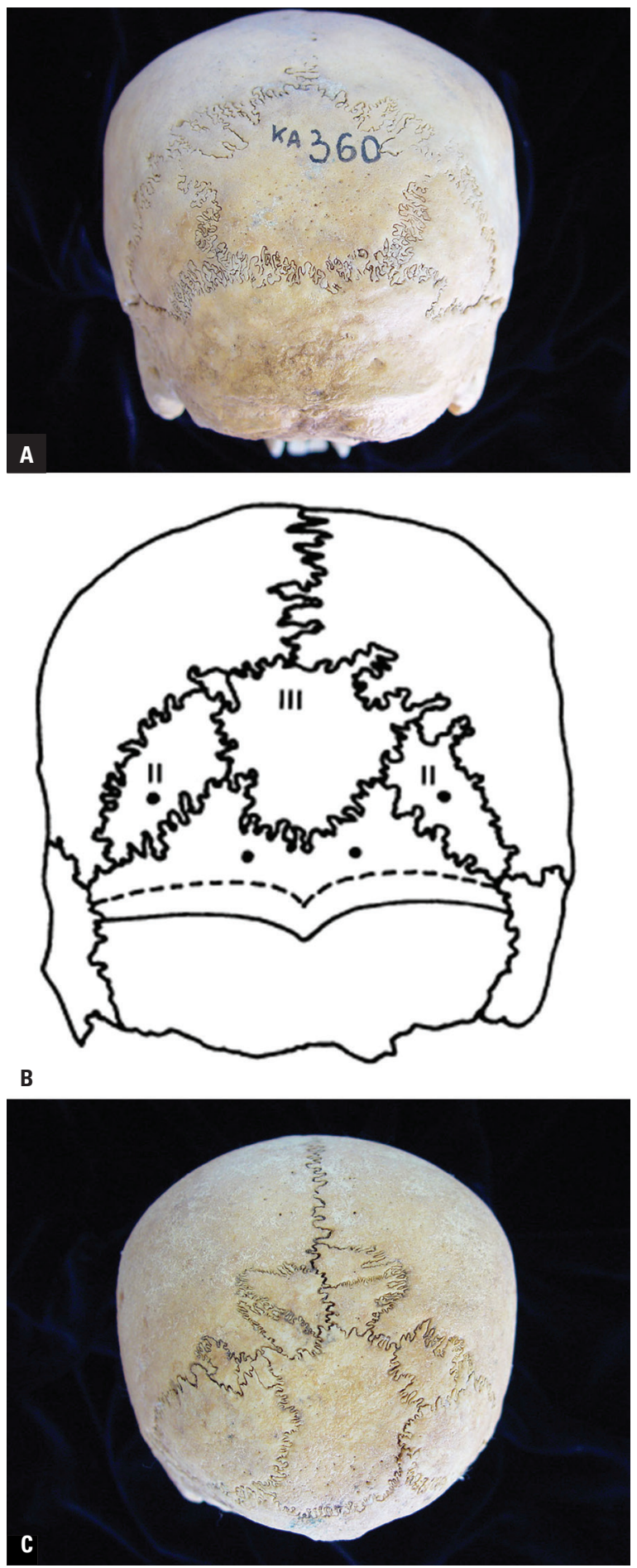

Figure 5. Os Incae tripartitum. A. In the medieval male series; B. A scheme suggested by Srivastava (1992): the central piece is formed by the $3^{\text {rd }}$ pair (III) and the lateral pieces by the lateral nuclei of the $2^{\text {nd }}$ pair (II); the medial nuclei of the $2^{\text {nd }}$ pair (II) have fused with each other and with the supraoccipital bone; C. A combination of $O$ s Incae tripartitum with sutural bones in the medieval female series.

bone, because of its irregular outline. Most probably it represented a posterior fontanel bone. 

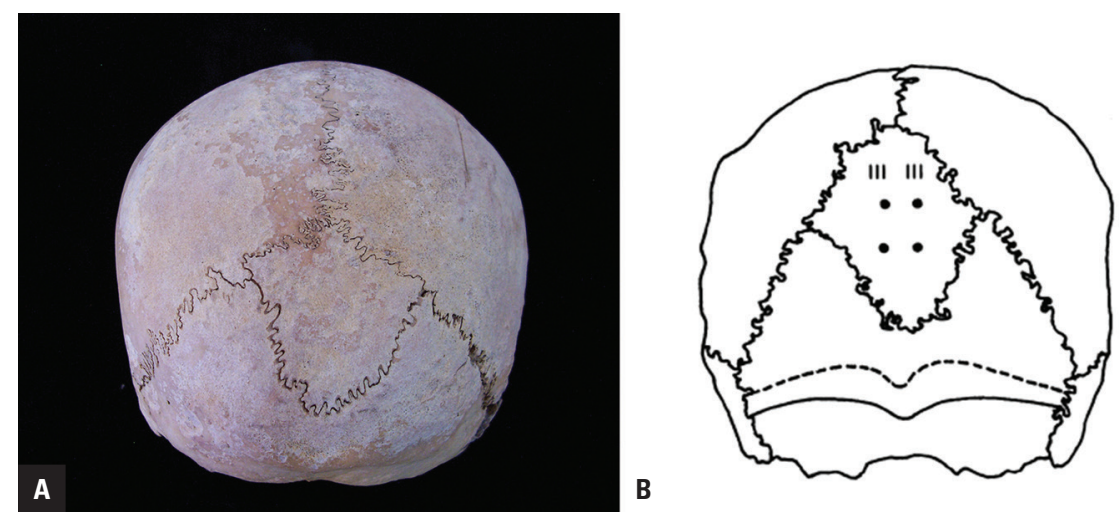

Figure 6. Os Incae centrale (medianum). A. In the medieval female series; B. A scheme suggested by Srivastava (1992): a central piece formed by the upper and lower nuclei of the $3^{\text {rd }}$ pair of centres (III). The lower limit of its suture lies above the highest nuchal line (dotted line).

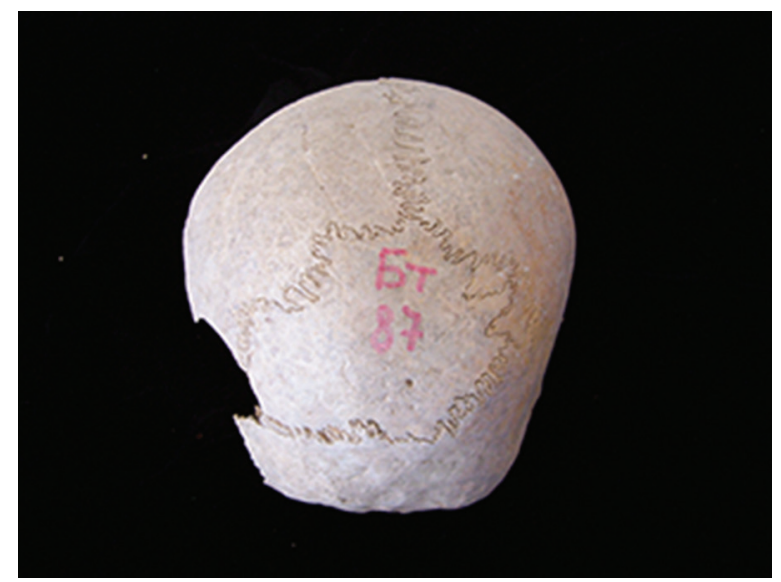

Figure 7. Os Incae Type II.1. according to the classification of Hanihara and Ishida (2001), in the medieval female series.

In the investigated 3 cranial series, no statistically significant sex or intergroup differences concerning the incidence of interparietal, preinterparietal and sutural bones in the lambda region were established.

\section{DISCUSSION}

The variations observed in the interparietal part of the occipital bone in adult skulls can be considered in terms of the detailed embryological observations of Srivastava [31] and Matsumura et al. [16]. The authors are in principal agreement, though they use differing terms for the same parts of the developing bone (Figs. 13, 14). They ascertain that the membranous part of the occipital bone develops from 3 pairs of ossification centres. The primary interparietal or the first pair appears in the third foetal month and its parts rapidly fuse with each other and then with the upper margin of the ossifying supraoccipital to
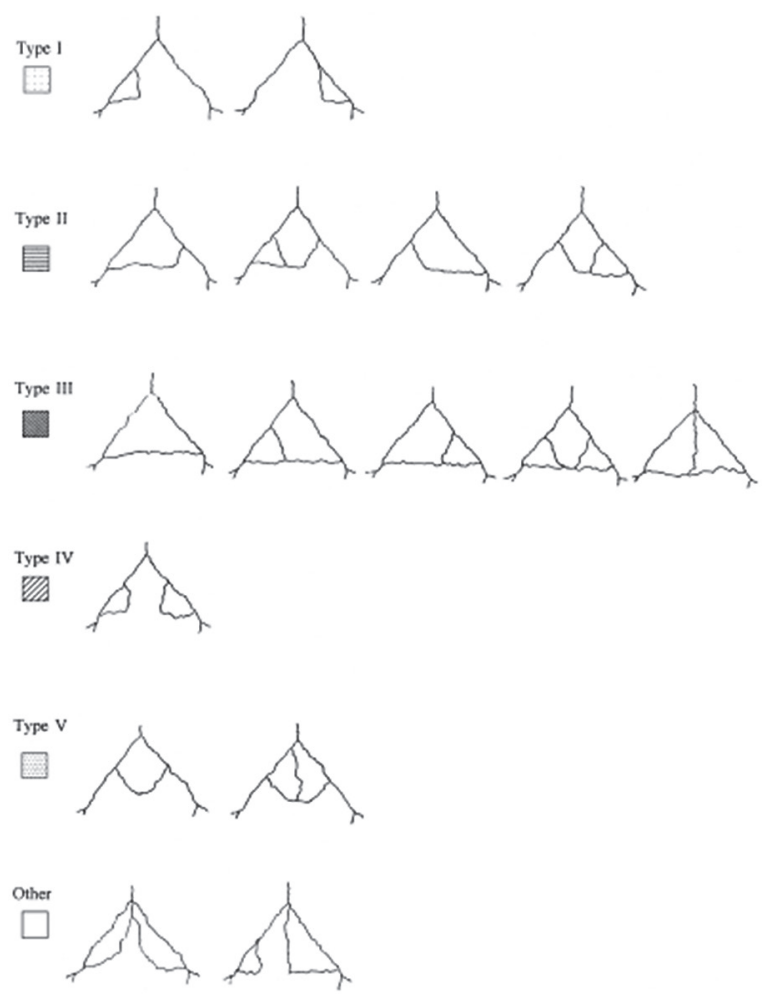

Figure 8. Classification of different types of os Incae after Hanihara and Ishida (2001).

form the torus occipitalis transversus. Srivastava [31] calls it an intermediate segment while Matsumura et al. [16] name it a primary interparietal. Later, in the third and fourth intrauterine months, two secondary interparietal pairs of centres (medial and lateral) appear anteriorly to the first (primary) pair and form the remaining part of the interparietal bone $[16,17$, 19]. Srivastava [31] calls these pairs of centres the second and third ones which form the lateral and 


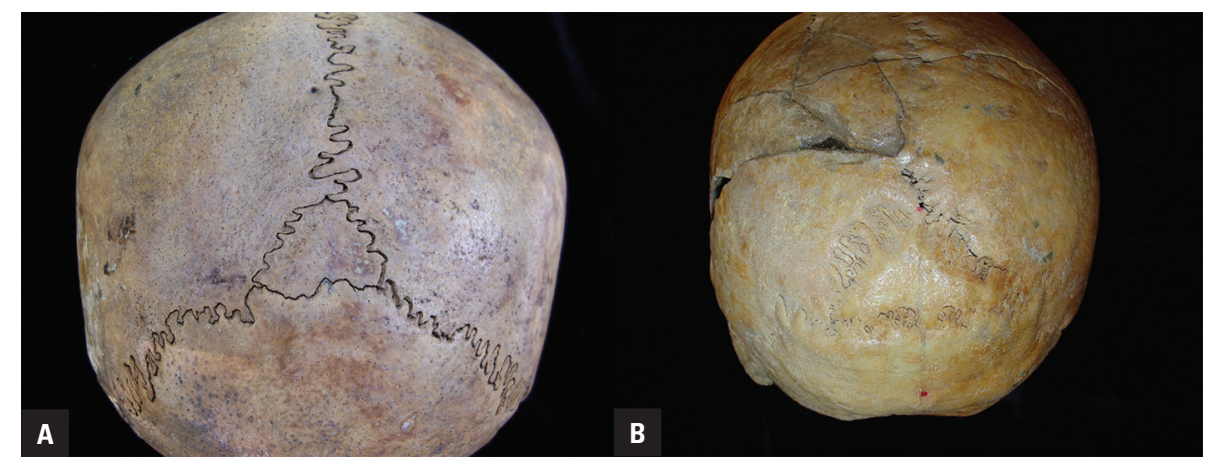

Figure 9. Single preinterparietal bone. A. In the contemporary male series situated at the posterior end of the sagittal suture; B. In the medieval male series within the territory of the interparietal.

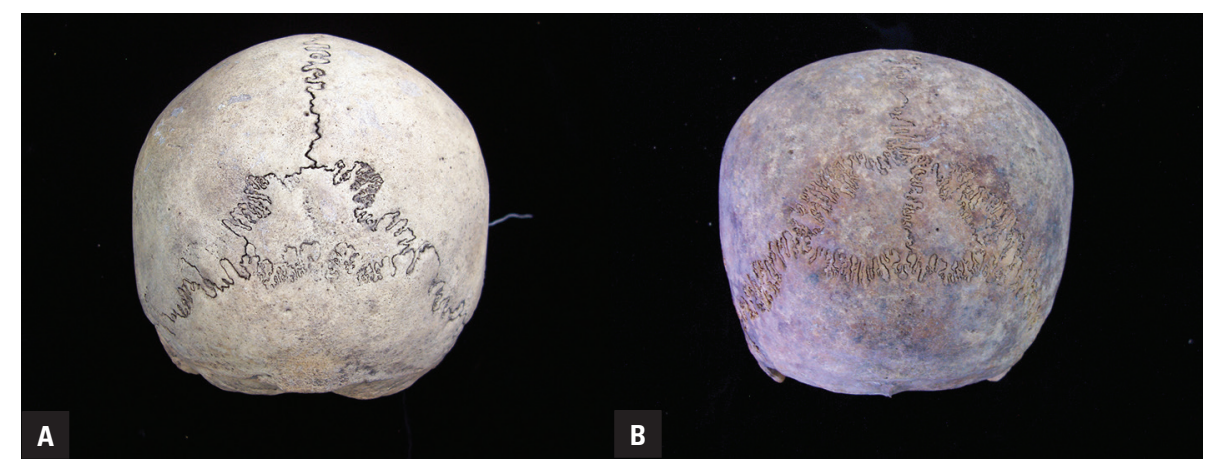

Figure 10. Bipartite preinterparietal bone. A. In the contemporary male series; B. In the medieval male series.

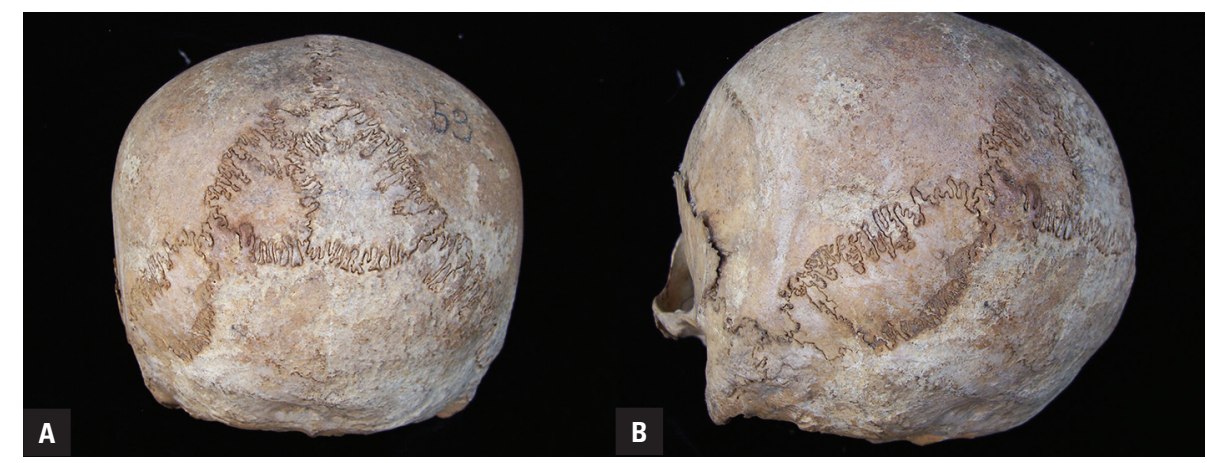

Figure 11. Os Incae laterale sinistrum in a combination with a multipartite preinterparietal bone in the contemporary male series. A. Occipital view; B. Left lateral view.

medial plates, respectively. According to Srivastava [31], each of the second and third pair of centres consists of 2 nuclei but this has not been observed and confirmed by Matsumura et al. [16]. Nevertheless, it is considered that the true interparietal or Inca bone develops above the highest nuchal line when the secondary centres (second and third pairs) fail to fuse with the primary ones (first pair). Thus, in adults the lower border of the interparietal bone lies at the level of highest nuchal line, i.e. on the demarcation line between the primary and secondary centres, which corresponds to the transverse occipital suture, also known as the lateral fissure, lateral notch or sutura mendosa [16, 19, 27, 31].

In the fifth foetal month, occasional ossification centres can appear anteriorly to the medial secondary 


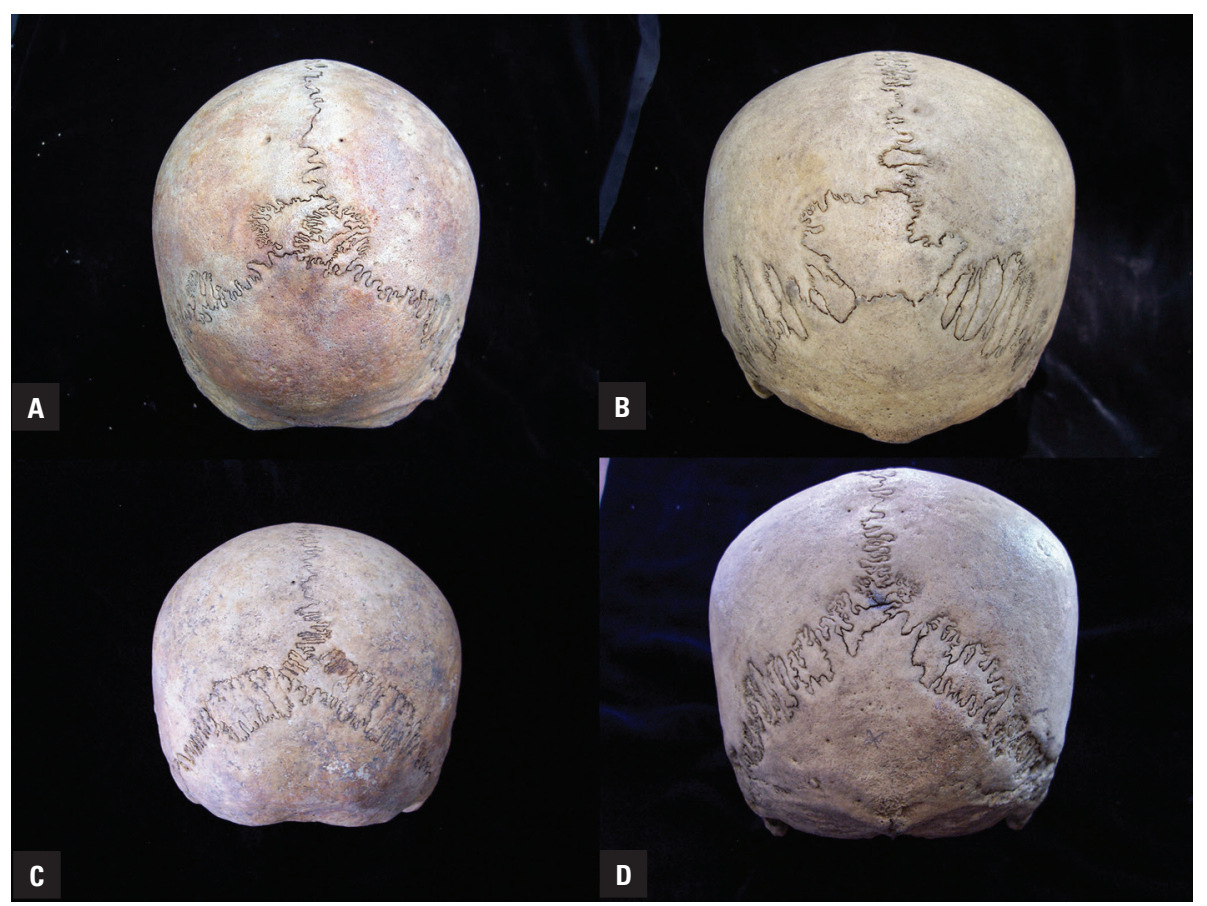

Figure 12. Sutural bones in the lambda region. A. A group of 4 sutural bones with irregular arrangement in the contemporary male series; B. A sutural bone in the contemporary male series probably representing the posterior fontanel bone; C, D. Irregular sutural bone in the medieval female series.

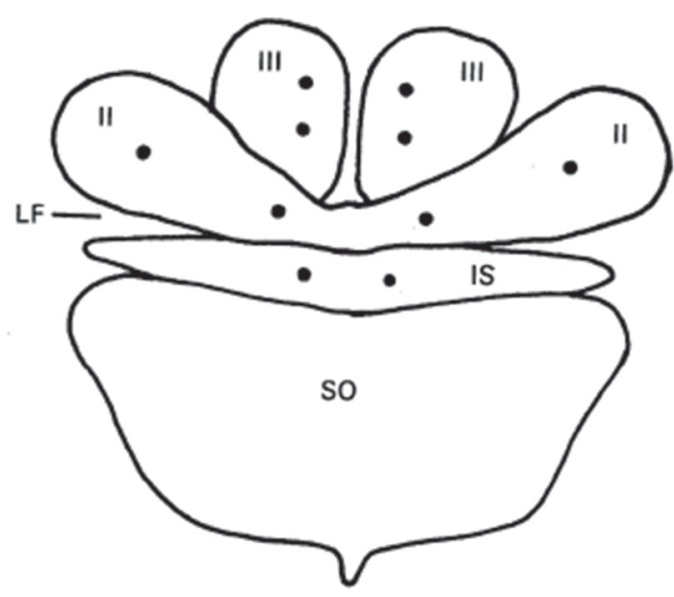

Figure 13. Diagrammatic representation of centres and their nuclei in the membranous part of the occipital bone above the supraoccipital (SO) bone after Srivastava (1992): paired centres of the intermediate segment (IS); medial and lateral nuclei of the $2^{\text {nd }}$ pair of centres (II); upper and lower nuclei of the $3^{\text {rd }}$ pair of centres (III); LF — lateral fissure.

interparietal centres, as an anlage of the preinterparietal bone [16]. According to Wiedersheim [34], these inconstant centres may remain partly or wholly separated. Furthermore, the preinterparietals are constantly present as a separate bone only in the horses,
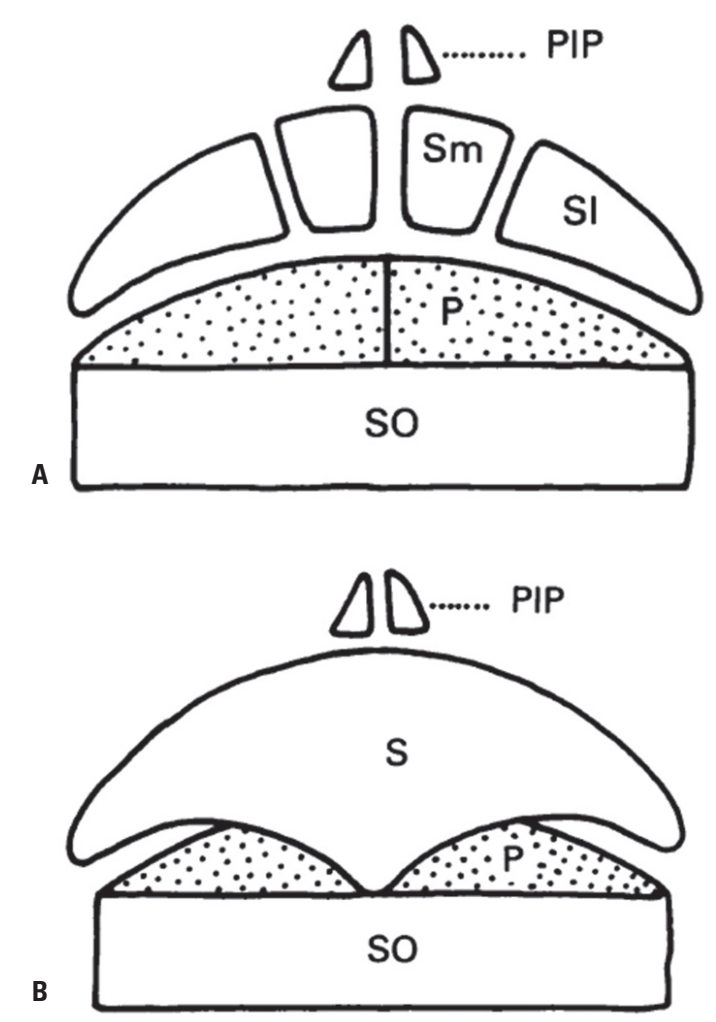

Figure 14. Ossification centres of the occipital squama $(\mathbf{A})$ and their development (B) according to Matsumura et al. (1993). $\mathrm{S}$ - secondary interparietal; SO — supraoccipital; $\mathrm{P}$ — primary interparietal; $\mathrm{SI}$ — lateral part of the secondary interparietal; $\mathrm{Sm}$ medial part of the secondary interparietal; PIP — preinterparietal. 
while in other mammals they are of more sporadic occurrence. In humans, the preinterparietals appear relatively frequently (1\%) [34]. Pal [22] and Pal et al. [23] describe the true preinterparietal as a triangular bone situated behind the lambda and separated from the remaining interparietal by a transverse suture. The latter develops from the occasional third pair of centres, part of the interparietal, which fails to fuse with the second pair of centres. Thus, the bone should be referred to as the upper central segment of the interparietal bone [22, 23]. According to Srivastava [31], there are no preinterparietals and the triangular bone in this area is the upper half of the central piece, in cases when the upper nuclei of the third pair of centres fail to unite with the lower nuclei and the remaining interparietal. Moreover, Srivastava [31] claims that all the bones developing in the lambda region and the lambdoid suture outside the limits of the interparietal area are sutural or Wormian bones with their own separate ossification centres. On the contrary, Matsumura et al. [17] notice that in foetal skulls the preinterparietal centres differ in texture and structure when compared with the surrounding bones and possess a clear outline. Furthermore, the preinterparietal centres show no apparent fusion with the surrounding bones during the foetal life so they can be independent of the surrounding bones, namely the parietals and the secondary interparietals. Faulty fusion of the preinterparietal centres could give rise to different kinds of variations in the adult skull. Occasionally, when the preinterparietal bone is located at the upper angle within the interparietal territory and fuses into the membranous squama, it can form the central upper portion of the interparietal. When the bone is situated at the posterior end of the sagittal suture, it can form a protrusion. Thus, in adults the preinterparietal bone should be positioned at the lambda region and its base should be located higher than the midline between the lambda and the highest nuchal line [16].

The presence of sutural or Wormian bones in the lambda region leads to additional confusions. The lambdoid suture is the most common place for the sutural bones [24]. Their presence is a normal variation, except for the cases when they are larger and numerous and can be an indicator for some congenital pathological conditions [20]. Notwithstanding, the sutural bones could be differentiated from the preinterparietals by their irregular arrangement and shape. According to Matsumura et al. [16], no sutural bone in the lambda region forms a triangular territory, nor does it cause an apparent depression on the upper edge of the interparietals. In addition, most of the sutural bones appear in the narrow space between the parietals and the interparietals after the sixth foetal month, whereas the preinterparietal centres appear in the fifth foetal month. According to some authors $[4,10]$, at the time of the initial closure of the posterior fontanel a typically localised sutural bone could develop. The bone tends to have a triangular, rounded or diamond shape and this description almost coincides with that of the preinterparietal bone.

Even though the various types of bones can be clearly differentiated at a younger age, the issue about their identification in adults still remains open. In the present study we use the definition "preinterparietal bones", despite the assertion of some authors that this term is "misnomer" and should be avoided [22, 31]. Obviously, further embryological investigations are necessary so as to establish if there are preinterparietal centres. Namely it must be clarified whether the preinterparietal bones can develop independently, or this notion is faulty and all variations are due to the failed fusion of separate nuclei of the interparietal centres or sutural bones. Matsumura et al. [16] prove that in some cases there are occasional ossification centres, which are not sutural. These differ from and are independent of the surrounding bones and can lead to clearly recognisable variations in the adult skull. In our opinion, even if the "preinterparietal bone" were not the appropriate term, another one ought to be suggested to designate this specific variation in adult skulls.

In their extensive study Kadanoff and Mutafov [10] reported that all types of os Incae verum (classic type) occurred in $2.84 \%$ (100 cases from 3,522 investigated skulls) in contemporary male cranial series from Bulgaria. On the other hand, the different types of os Incae spuriae (variations of the classic type or false Inca bone) occurred in $0.62 \%$ ( 22 cases of 3,522 skulls). It must be noted that the authors did not distinguish the interparietal from the preinterparietal bones, which makes their results incomparable to our findings. The authors describe incidences of os Incae with a small size which are hard to distinguish from os apicis lambdae i.e. the posterior fontanel bone. Most probably in some of the cases, there is a presence of preinterparietal bones. Furthermore, the authors describe the os apicis as a triangular, rhomboid or 
rounded bone, in the site of the posterior fontanel, between the 2 parietal bones, which could be paired or multipartite. They differentiate os apicis from other sutural bones by its typical location and outline.

This description almost corresponds to that of the preinterparietal bones supposed by Matsumura et al. [16]. Moreover, Kadanoff and Mutafov [10] accept that the demarcation line for os Incae is sutura occipitalis transversa (cranii) which is not the same as the sutura mendosa. As evidence for this assertion, the authors report cases in which remnants of the sutura mendosa were simultaneously observed with os Incae. In view of the embryological investigations described above, we suppose that most probably in the above-mentioned cases there was a remnant of the sutura mendosa along with the preinterparietal bone. This is similar to our case presented in Figure 11 and discussed below.

In this study one of the skulls has os Incae laterale sinistrum along with a multipartite preinterparietal bone (see Fig. 11A, B). As it can be seen, the lower end of the interparietal bone lies at the highest nuchal line while the lower end of the preinterparietal bone lies slightly above the midline between the lambda and the highest nuchal line. The interparietal bone i.e. os Incae laterale sinistrum, most probably was formed through a faulty fusion between the left lateral part of the secondary interparietal pair of centres [16] or left lateral nucleus of the second pair [31] and the remaining interparietal. We call the upper bone preinterparietal in accordance with the definition of Matsumura et al. [16], because of its position and outline. In fact, we cannot be certain of the true embryological origin of this bone. Since we examine adult skulls, we cannot claim for sure if such a variation is due either to the occasional preinterparietal pair of centres [16] or to faulty fusion between the upper nuclei of the third pair of centres [31]. For this reason, and also because of the limitation of subjectivity in the interpretation of the occurring variations in the occipital squama in adult skulls, we suggest the following criteria:

Interparietal or Inca bone (os Incae) - its base is located slightly above the external occipital protuberance at the level of the highest nuchal line, i.e. the lower border lies on the demarcation line between the primary and secondary centres, corresponding to the sutura mendosa. The different types of os Incae are well illustrated by Kadanoff and Mutafov $[9,10]$ and Hanihara and Ishida [8]. Using these schemes we are to bear in mind that the lower border of the bone or at least one section of it should be at the level of the highest nuchal line or slightly above it.

Preinterparietal - a single bone or a group of bones with a different size, separated by the transverse suture and forming a triangular territory in the central lambda region. Occasionally they form a triangular protrusion in the posterior part of the sagittal suture between the two parietal bones. Their bases are located higher than the midline between the lambda and the highest nuchal line. They can be single, bipartite, tripartite or multipartite.

Sutural or Wormian bones - a single bone or a group of bones located in the region of the lambda which are irregular in their arrangement and shape. They can be small or large in size but in contrast to the preinterparietal bones they do not show a triangular outline.

Posterior fontanel bone - a relatively large sutural bone in the area of the posterior fontanel with an irregular or rounded shape. In our opinion, it is quite enough to determine whether a bone is sutural or not without specifying if it is namely the posterior fontanel bone.

Lastly, we believe that our summarised criteria can be useful to other researchers for the recognition, description and comparison of the variations in the squamous part of the occipital bone and the lambda region.

\section{CONCLUSIONS}

In the investigated 3 cranial series, the different types of interparietal bone were observed with a low frequency. The incidences of preinterparietal bones were more common in comparison with the interparietal ones. The incidences of sutural bones in the lambda region were numerous. No statistically significant sex or intergroup differences were established.

Knowledge of the variations occurring in the occipital squama and the lambda region is of theoretical and practical significance. Moreover, the understanding of these variations is of importance for both comparative and developmental anatomy. They can also be used as non-metric cranial traits in the assessment of the differences between population groups. In forensic medicine such variations contribute significantly for the identification of deceased, especially when they are compared with the available antemortem records [1]. Last but not least, their identification and proper description can also be of use for 
the clinical practice in the correct interpretation of skull radiographs and the avoidance of diagnostic errors.

\section{ACKNOWLEDGEMENTS}

This work was supported by the European Social Fund and Republic of Bulgaria, Operational Programme "Human Resources Development" 2007-2013 framework, Grant No BG051P0001-3.3.06-0048 from 04.10.2012.

\section{REFERENCES}

1. Badkur DS, Sharma V, Badkur P (2011) Medicolegal Importance of Inca Bone in Forensic Identification. J Indian Acad Forensic Med, 33: 358-360.

2. Bhanu PS, Sankar KD (2011) Interparietal and pre-interparietal bones in the population of south coastal Andhra Pradesh, India. Folia Morphol, 70: 185-190.

3. Das S, Suri R, Kapur V (2005) Anatomical observations on os inca and associated cranial deformities. Folia Morphol, 64: 118-121.

4. El-Najjar MY, McWilliams KR (1978) Forensic anthropology. Charles C. Thomas Publisher, Springfield.

5. Gopinathan, K. (1992) A rare anomaly of 5 ossicles in the pre-interparietal part of the squamous occipital bone in north Indians. J Anat, 180: 201-202.

6. Goyal N, Gupta M, Aggarwal B (2012) A study of the interparietal bones. J Clin Diagn Res, 6: 761-763.

7. Gözil R, Çalgüner E, Keskil S (1994) Incidence of interparietal and preinterparietal bones in adult skulls from Central Anatolia region. Gazi Med J, 5: 123-125.

8. Hanihara T, Ishida H (2001) Os Incae: Variation in frequency in major human population groups. J Anat, 198: 137-52.

9. Kadanoff D, Mutafov S (1964) Os incae bei Bulgaren. Morphol Jahrb, 105, 602-615.

10. Kadanoff D, Mutafov S (1984) The human skull in a medico-anthropological aspect: form, dimensions and variability. Prof. Marin Drinov Academic Publishing House, Sofia [in Bulgarian].

11. Khan AA, Asari MA, Hassan A (2011) Unusual presence of Wormian (sutural) bones in human skulls. Folia Morphol, 70: 291-294.

12. Khan AA, Ullah M, Asari MA, Hassan A (2013) Interparietal bone variations in accordance with their ossification centres in human skulls. Int J Morphol, 31: 546-552.

13. Kumud D (2011) Os Incae morphometric, clinical and medicolgal perspective. J Anat Soc India, 60: 218-223.

14. Marathe RR, Yogesh AS, Pandit SV, Joshi M, Trivedi GN (2010) Inca-interparietal bones in neurocranium of human skulls in central India. J Neurosci Rural Pract, 1: 14-16.

15. Martin R, Saller K (1957) Lehrbuch der anthropologie in sistematischer darstellung, Band I, Gustav Fisher Verlag, Stuttgart.
16. Matsumura G, Uchiumi T, Kida K, Ichikawa R, Kodama G (1993) Developmental studies on the interparietal part of the human occipital squama. J Anat, 182: 197-204.

17. Matsumura G, England MA, Uchiumi T, Kodama G (1994) The fusion of ossification centres in the cartilaginous and membranous parts of the occipital squama in human fetuses. J Anat, 185: 295-300.

18. Murlimanju BV, Prabhu LV, Paul MT, Pai MM, Krishnamurthy A, Rai A (2010) Variant morphogenesis of squamous part of occipital bone in human skulls. J Morphol Sci, 27: 139-141.

19. Niida S, Yamasaki A, Kodama H (1992) Interference with interparietal growth in the human skull by the tectum synoticum posterior. J Anat, 180: 197-200.

20. Nikolova SY, Toneva DH, Yordanov YA, Lazarov NE (2014) Multiple Wormian bones and their relation with definite pathological conditions in a case of an adult cranium. Anthrop Anz, 71: 169-190.

21. Nirmale V, Laeeque M, Diwan CV (2012) Variation in frequency of os Incae in human skull. Int J Basic Med Science, 3: 39-44.

22. Pal GP (1987) Variations of the interparietal bone in man. J Anat, 152: 205-208.

23. Pal GP, Tamankar BP, Routal RV, Bhagwat SS (1984) The ossification of the membranous part of the squamous occipital bone in man. J Anat, 138: 259-266.

24. Parker CA (1905) Wormian bones. Roberts Press, Chicago.

25. Patel BG, Patel JP, Shah RK, Kanani SD, Nirvan AB, Dave RV (2014) Morphometric study of interparietal bone in Gujarat region. Int J Med Sci Public Health, 3: 108-110.

26. Saxena SK, Chowdhary DS, Jain SP (1986). Interparietal bones in Nigerian skulls. J Anat, 144: 235-237.

27. Scheuer L, Black S (2000) Developmental Juvenile Osteology. Academic Press, London.

28. Shah K, Shah P, Shah S (2013) Study of interparietal bone in 100 human skulls. Int J Scientific Res, 2: 466.

29. Shapiro R, Robinson F (1976) The Os Incae. Am J Roentgenol, 127: 469-471.

30. Srivastava HC (1977) Development of ossification centres in the squamous portion of the occipital bone in man. J Anat, 124: 643-649.

31. Srivastava HC (1992) Ossification of the membranous portion of the squamous part of the occipital bone in man. J Anat, 180: 219-224.

32. Udupi S, Srinivasan JK (2011) Interparietal (Inca) bone: a case report. Int J Anat Variations, 4: 90-92.

33. Verma P, Arora AK (2012) A case report of quadrangular Inca bone. Rev Arg De Anat Clin, 4: 97-101.

34. Wiedersheim $R$ (1895) The structure of man an index to his past history. Macmillan and Co, London.

35. Yücel F, Eğilmez H, Akgün Z (1998) A study on the interparietal bone in man. Tr J Med Sci, 28: 505-510.

36. Zambare BR (2001) Incidence of interparietal bones in adult skulls. J Anat Soc India, 50: 11-12. 